\title{
A Partial Bison (Bison cf. B. latifrons) Skeleton from Chuchi Lake, and its Implications for the Middle Wisconsinan Environment of Central British Columbia Les liens entre la présence d'un squelette de bison géant (Bison cf. B. latifrons) au Chuchi Lake et la nature de l'environnement au Wisconsinien moyen au centre de la Colombie-Britannique Teile eines Bison-Skeletts (Bison cf. B. latifrons) vom See Chuchi und seine Bedeutung für die Umwelt im Zentrum von British Columbia im mittleren Wisconsinium
}

\section{Richard Harington, Alain Plouffe et Hélène Jetté}

Volume 50, numéro 1, 1996

URI : https://id.erudit.org/iderudit/033076ar

DOI : https://doi.org/10.7202/033076ar

\section{Aller au sommaire du numéro}

\section{Éditeur(s)}

Les Presses de l'Université de Montréal

\section{ISSN}

0705-7199 (imprimé)

1492-143X (numérique)

\section{Découvrir la revue}

\section{Citer cet article}

Harington, C. R., Plouffe, A. \& Jetté, H. (1996). A Partial Bison (Bison cf. B. latifrons) Skeleton from Chuchi Lake, and its Implications for the Middle Wisconsinan Environment of Central British Columbia. Géographie physique et Quaternaire, 50(1), 73-80. https://doi.org/10.7202/033076ar

\section{Résumé de l'article}

On a trouvé au lac Chuchi dans une unité d'argile recouverte d'un diamicton de la dernière glaciation (Fraser), des fragments de noyaux de cornes droite et gauche et des ossements postcrâniens qui pourraient provenir du bison géant (Bison cf. B. latifrons). Un échantillon d'un des noyaux de corne a été daté au radiocarbone par spectrométrie de masse par accélérateur à $30740 \pm 220 \mathrm{BP}$, alors qu'un humérus du même horizon a été daté dans deux différents laboratoires à $34800 \pm 420 \mathrm{BP}$ et $35480 \pm 1080 \mathrm{BP}$. Malgré la différence entre les dates du noyau de corne et de l'humérus, celles-ci concordent avec l'âge stratigraphique présumé de l'unité d'argile où les ossements ont été trouvés. L'analyse du pollen de la même unité d'argile indique que le bison vivait dans une forêt ouverte. Selon les données paléoenvironnementales du Babine Lake, où on a trouvé un mammouth du même âge, il est probable que le bison et le mammouth colombien partageaient un milieu variant entre la forêt ouverte et la toundra arbustive parsemée de lacs, au centre de la Colombie-Britannique, pendant le Wisconsinien moyen (intervalle non glaciaire de l'Olympia). La découverte du spécimen du Chuchi Lake est d'autant plus importante qu'il constitue le premier indice de la présence du bison géant en Colombie-Britannique; il pourrait être parmi les derniers survivants de cette espèce.
Tous droits réservés @ Les Presses de l'Université de Montréal, 1996
Ce document est protégé par la loi sur le droit d'auteur. L’utilisation des services d'Érudit (y compris la reproduction) est assujettie à sa politique d'utilisation que vous pouvez consulter en ligne.

https://apropos.erudit.org/fr/usagers/politique-dutilisation/ 


\section{A PARTIAL BISON (Bison cf. B. latifrons) SKELETON FROM CHUCHI LAKE, AND ITS IMPLICATIONS FOR THE MIDDLE WISCONSINAN ENVIRONMENT OF CENTRAL BRITISH COLUMBIA*}

C. Richard HARINGTON, Alain PLOUFFE and Hélène JETTÉ, respectively Canadian Museum of Nature (Paleobiology), Ottawa, Ontario K1P 6P4, Geological Survey of Canada, 601 Booth Street, Ottawa, Ontario K1A OE8, and Natural Resources Canada, 580 Booth Street, Ottawa, Ontario K1A 0E4.

\begin{abstract}
Fragmentary but massive left and right horncores, found with eight postcranial bones, from a clay unit underlying a diamicton of the last (Fraser) glaciation at Chuchi Lake, British Columbia probably represents an individual giant bison (Bison cf. $B$. latifrons). A sample of bone from one of the horncores yielded an accelerator mass spectrometry (AMS) radiocarbon date of $30740 \pm 220 \mathrm{BP}$, whereas overlapping dates from two other laboratories on an associated humerus are $34800 \pm 420 \mathrm{BP}$ and $35480 \pm$ 1080 BP. Despite the discrepancy between horncore and humerus dates, they are in accord with the suspected stratigraphic age of the clay unit whence they came. Analysis of pollen from that clay unit indicates that bison with massive horns once occupied an open forest in the vicinity. Probably giant bison and Columbian mammoths (incorporating paleoenvironmental evidence found with the nearby, penecontemporaneous Babine Lake mammoth) shared lake-dotted open forest to shrub tundra range in what is now central British Columbia toward the close of the Middle Wisconsinan (Olympia Nonglacial Interval). The Chuchi Lake specimen is important because it is the first indication of giant bison from British Columbia, and it appears to be one of the latest known survivors of this species.
\end{abstract}

RÉSUMÉ Les liens entre la présence d'un squelette de bison géant (Bison cf. B. latifrons) au Chuchi Lake et la nature de l'environnement au Wisconsinien moyen au centre de la Colombie-Britannique. On a trouvé au lac Chuchi dans une unité d'argile recouverte d'un diamicton de la dernière glaciation (Fraser), des fragments de noyaux de cornes droite et gauche et des ossements postcrâniens qui pourraient provenir du bison géant (Bison cf. B. latifrons). Un échantillon d'un des noyaux de corne a été daté au radiocarbone par spectrométrie de masse par accélérateur à $30740 \pm 220 \mathrm{BP}$, alors qu'un humérus du même horizon a été daté dans deux différents laboratoires à $34800 \pm$ $420 \mathrm{BP}$ et $35480 \pm 1080 \mathrm{BP}$. Malgré la différence entre les dates du noyau de corne et de l'humérus, celles-ci concordent avec l'âge stratigraphique présumé de l'unité d'argile où les ossements ont été trouvés. L'analyse du pollen de la même unité d'argile indique que le bison vivait dans une forêt ouverte. Selon les données paléoenvironnementales du Babine Lake, où on a trouvé un mammouth du même âge, il est probable que le bison et le mammouth colombien partageaient un milieu variant entre la forêt ouverte et la toundra arbustive parsemée de lacs, au centre de la Colombie-Britannique, pendant le Wisconsinien moyen (intervalle non glaciaire de l'Olympia). La découverte du spécimen du Chuchi Lake est d'autant plus importante qu'il constitue le premier indice de la présence du bison géant en ColombieBritannique; il pourrait être parmi les derniers survivants de cette espèce.

\footnotetext{
Manuscrit reçu le 1er mai 1995 ; manuscrit révisé accepté le 21 novembre 1996

* Contribution no. 12595 of the Geological Survey of Canada
}

ZUSAMMENFASSUNG Teile eines BisonSkeletts (Bison cf. B. latifrons) vom See Chuchi und seine Bedeutung für die Umwelt im Zentrum von British Columbia im mittleren Wisconsinium. Fragmentarische aber massive linke und rechte Hornkerne zusammen mit acht Hinterschädelknochen, die man in einer Lehm-Einheit unter einem Diamikton der letzten Vereisung (Fraser) am See Chuchi, British Columbia, gefunden hat, könnten wohl von einem einzelnen Riesenbison stammen (Bison cf. B. latifrons). Für eine Knochenprobe von einem der Hornkerne wurde mittels Massenspektrometrie durch Beschleuniger ein Radiokarbondatum von $30740 \pm 220$ v.u.Z. ermittelt, während zwei andere Labore sich überschneidende Daten auf einem damit in Verbindung gebrachten Oberarmknochen ermittelten: $34800 \pm 420$ v.u.Z. und 35480 \pm 1080 v.u.Z. Trotz der Diskrepanz zwischen den Hornkern- und Oberarmknochendaten, stimmen sie mit dem vermuteten stratigraphischen Alter der Lehmeinheit, aus der sie stammen, überein. Die PollenAnalyse von dieser Lehmeinheit zeigt, daß ehemals Bisons mit massiven Hörnern in einem offenen Wald in der Nähe lebten. Gegen Ende des mittleren Wisconsiniums (nichtglaziales Intervall von Olympia) teilten sich wahrscheinlich Riesenbisons und kolumbianische Mammuts (wenn man die Paläoumweltbelege von Babine Lake berücksichtigt, wo man ein Mammut des gleichen Alters gefunden hat) ein Gebiet, das von Seen durchsetzten offenen Wald bis zur Buschtundra enthielt und dem heutigen Zentrum von British Columbia entspricht. Das Exemplar von Chuchi Lake ist wichtig, weil es der erste Hinweis auf Riesenbison von British Columbia ist, und es scheint eines der letzten bekannten Überlebenden dieser Art zu sein. 


\section{INTRODUCTION}

During the summer of 1967, P. Koropatnisky, a resident of Chuchi Lake, found a cluster of bison bones including horncores embedded in gray clay along the Nation River, approximately $1.2 \mathrm{~km}$ from the outlet of Chuchi Lake (Fig. 1). He notified C.E. Borden of the Museum of Anthropology, University of British Columbia, who visited the site, examined the bones and made the necessary arrangements to store and preserve them. In 1991 A.P., who was starting a regional surficial sediment mapping project in the area, met Koropatnisky and learned about the discovery of bison remains along the Nation River. They revisited the bison site together to properly identify it and the stratigraphic unit where the bones were recovered. A.P. then contacted the University of British Columbia Museum of Anthropology (D. Pokotylo) to borrow the bones in order to have them identified and possibly determine their age. The specimens were sent to C.R.H. who described them and identified the animal as a bison with massive horns, probably Bison latifrons. The purpose of this paper is to outline the stratigraphy of the site and to report on the radiocarbon age determinations (A.P.), to describe and discuss the nature of the bison remains (C.R.H.), to report on a palynological investigation of the enclosing sediments (H.J. and A.P.) and to discuss the find in relation to the regional Pleistocene stratigraphy.

\section{GEOLOGICAL SETTING}

The bison site (91-264) is located along the Nation River $\left(55^{\circ} 11^{\prime} 29^{\prime \prime} \mathrm{N}, 124^{\circ} 22^{\prime} 51^{\prime \prime} \mathrm{W}\right.$, at $875 \mathrm{~m}$ above sea level) (Fig. 1). The bones were recovered beneath $6.5 \mathrm{~m}$ of unconsolidated sediments. Plouffe (1992) has reported on the Quaternary stratigraphy exposed along the Nation River. Station numbers and stratigraphy are the same as in that publication except for the lowermost stratigraphic unit at site 91-264, which was added following more recent field work.

The bones were recovered near the base of section 91264 in a well-laminated silt and clay unit (Unit 1; Fig. 2). At this site, Unit 1 is exposed only in late summer and early autumn when the river is lowest (P. Koropatnisky, pers. comm., 1993). It consists of couplets of silt and clay laminae. Unit 1 is exposed at a few places along the Nation River, and at every site, couplets have a thickness which varies among the sites from 5 to $10 \mathrm{~cm}$ (Fig. 3). Rare organic debris, including shell fragments and wood, too compressed to be identified, were found within this unit at section 91-264. The unit could represent (1) lacustrine sediments deposited during a nonglacial interval, or (2) glaciolacustrine sediments containing reworked organic debris deposited in a proglacial lake.

This lower unit is separated by an erosional contact from an overlying $2.5 \mathrm{~m}$-thick massive and well-compacted

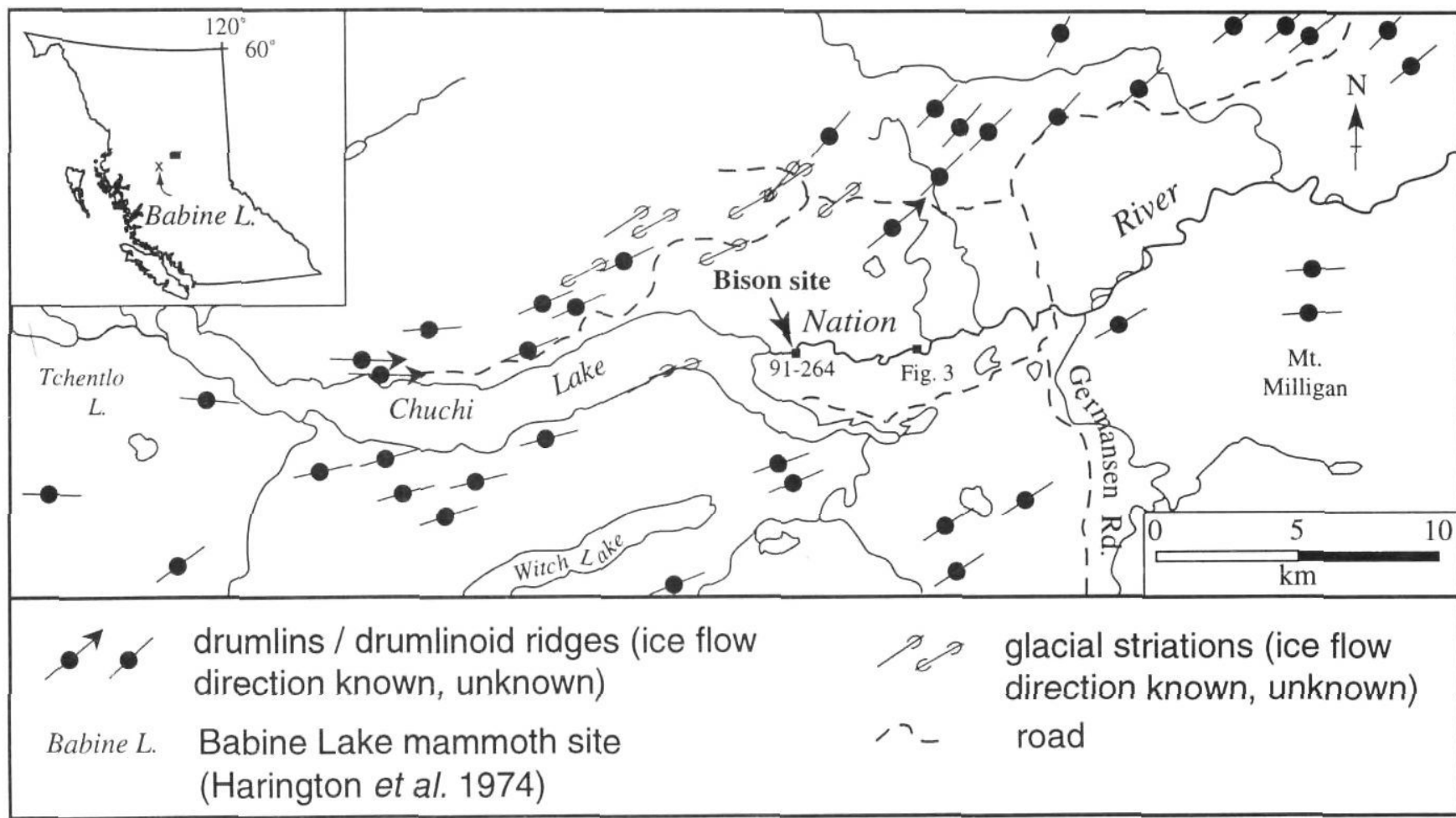

FIGURE 1. Map of Chuchi Lake with ice-flow directions and bison site (station 91-264). Inset shows position of map area in relation to the rest of British Columbia, as well as the Babine Lake mammoth site.
Carte de la région du Chuchi Lake avec les directions de l'écoulement glaciaire et la coupe 91-264 où les ossements de bison ont été trouvés. Le carton donne l'emplacement de la région par rapport à l'ensemble de la Colombie-Britannique ainsi que le site des ossements de mammouth du Babine Lake. 
FIGURE 2. Stratigraphic column of section 91-264. Legend modified from Eyles and Miall (1984). Position of bison (Bison cf. B. latifrons) bones is marked by an asterisk.

Colonne stratigraphique de la coupe 91-264 (légende modifiée à partir de celle de Eyles et Miall, 1984). L'emplacement des ossements de Bison cf. B. latifrons est donné par un astérisque.

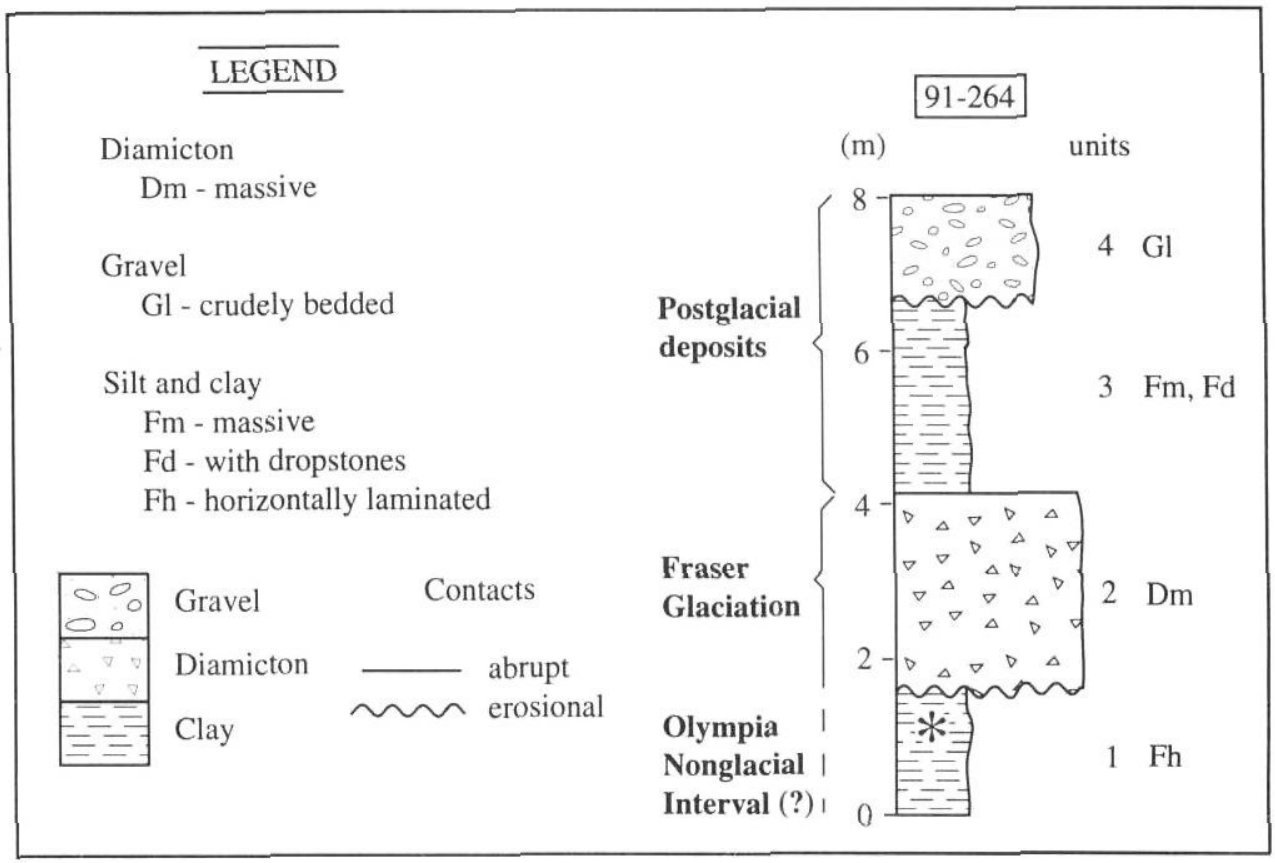

diamicton (Unit 2; Fig. 2), containing striated clasts of various sizes with a predominance of local rocks. This diamicton is identified as a till by the presence of erratic striated clasts and compaction of the matrix. The till was deposited during the Late Wisconsinan (Fraser) glaciation when ice was flowing to the east and northeast, as deduced from a number of drumlinoid features measured on air photos and from observations of striated bedrock (Fig. 1).

A massive unit of fine, well-sorted gray silt and clay with rare clasts (Unit 3; Fig. 2) abruptly overlies Unit 2 . The nature of the sediments imply that they were deposited in a lowenergy environment such as a body of water, most likely a glacial lake (note the presence of dropstones). A glacial lake existed during the retreat of the ice from the area according to evidence found farther downstream along the Nation River (Plouffe, 1992).

Unit 3 is overlain by $1.5 \mathrm{~m}$ of crudely-bedded sand and gravel (Unit 4; Fig. 2). This unit represents the surface sediments of the alluvial terrace through which section 91 264 was cut. It is interpreted as fluvial sediments deposited during a period of aggradation at the end of the Fraser Glaciation, i.e. during paraglaciation (e.g. Jackson et al., 1982; Church and Ryder, 1972).

\section{AGE}

Unit 1 was deposited during a time interval that predates the advance of Fraser Glaciation ice in the area. The Olympia Nonglacial Interval commenced more than $59 \mathrm{ka}$ ago and ended at the beginning of the Fraser Glaciation 25 to $29 \mathrm{ka}$ ago (Ryder and Clague, 1989). Sediments of Unit 1 might have been deposited (1) during the Olympia Nonglacial Interval, (2) at the beginning of the Fraser Glaciation, or (3) in an older glaciolacustrine or lacustrine environment. Three radiocarbon age determinations on the collagen fraction of two

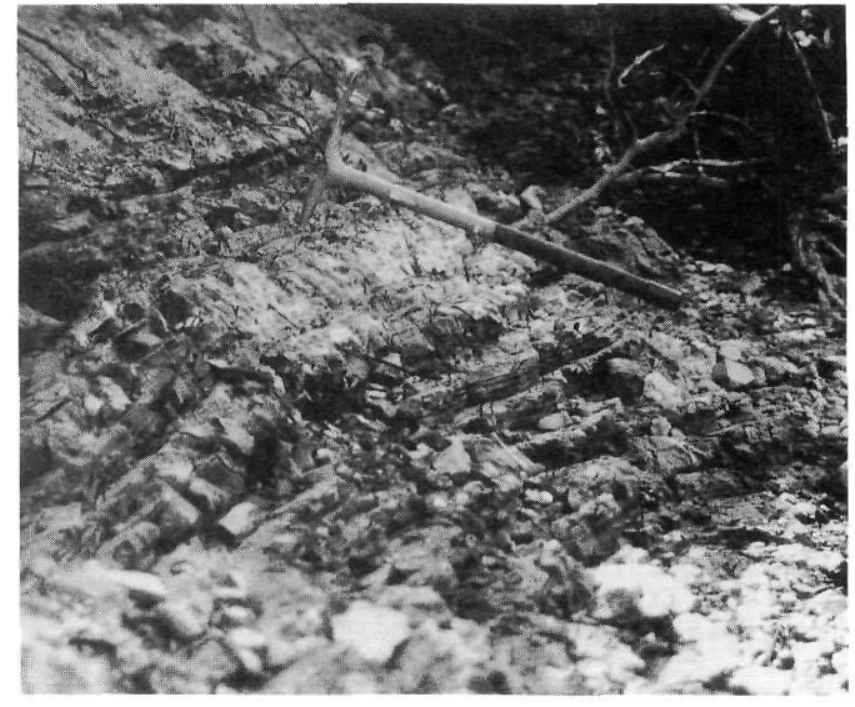

FIGURE 3. Photograph (GSC no. 1994-395) of laminated silt and clay unit exposed approximately $4 \mathrm{~km}$ downstream from the bison site and correlated with Unit 1 of station 91-264 - the unit from which the bison bones were recovered. This site is located on Figure 1.

Photographie (CGC n 1994-395) de l'unité d'argile et de silt laminé mise au jour $4 \mathrm{~km}$ en aval du site des ossements de bison et corrélée avec l'unité 1 de la station 91-264, là où les ossements ont été trouvés (voir la fig. 1)

of the bones [horncore: $30740 \pm 220 \mathrm{BP}$ (TO-3653) and humerus: $34800 \pm 420 \mathrm{BP}$ (Beta-78573, CAMS-17566) and $35480 \pm 1080 \mathrm{BP}$ (Beta-78574); Table I] suggest that the third scenario is the most unlikely. We consider it probable that the radiocarbon ages on the bones approach the maximum age of Unit 1 since its couplets are either rhythmites or varves, suggesting that the entire unit may represent only a few hundred years of sedimentation. 
TABLE ।

Radiocarbon data on the Chuchi Lake bison

\begin{tabular}{|c|c|c|c|c|c|}
\hline \multirow{2}{*}{$\begin{array}{l}\text { Laboratory } \\
\text { Number }\end{array}$} & \multirow{2}{*}{$\begin{array}{c}\text { Date } \\
\text { (yrs BP) }\end{array}$} & \multirow[t]{2}{*}{ Technique } & \multirow{2}{*}{$\begin{array}{l}\text { Specimen } \\
\text { sampled }\end{array}$} & \multicolumn{2}{|c|}{ *Sample Weight } \\
\hline & & & & submitted & collagen \\
\hline TO-3653 & $30740 \pm 220$ & AMS & $\begin{array}{l}\text { horncore } \\
47 \mathrm{M} 38 \mathrm{~A}\end{array}$ & $2.9 \mathrm{~g}$ & $5.5 \mathrm{mg}$ \\
\hline \multicolumn{6}{|l|}{ Beta-78573 } \\
\hline CAMS 17566 & $34800 \pm 420$ & AMS & $\begin{array}{l}\text { humerus } \\
47 \mathrm{M} 3\end{array}$ & 30.64 mg & $18.6 \mathrm{mg}$ \\
\hline Beta-78574 & $35480 \pm 1080$ & standard & $\begin{array}{l}\text { humerus } \\
47 \mathrm{M} 3\end{array}$ & $510.5 \mathrm{~g}$ & $6.6 \mathrm{~g}$ \\
\hline
\end{tabular}

* Collagen weight used for dating.

Comments: Specimens were collected by P. Koropatnisky along the Nation River $1.2 \mathrm{~km}$ from the outlet of Chuchi Lake, B.C. (55 $111^{\prime 2} 29^{\prime \prime} \mathrm{N}$, $\left.124^{\circ} 22^{\prime} 51^{\prime \prime} \mathrm{W}\right)$.

Taking the radiocarbon dating error factor into consideration, the minimum age difference between the horncore and humerus is 3420 years. Because the collagen was extracted from the horncore and humerus at different laboratories using slightly different techniques (TO-3653 collagen extracted at IsoTrace Laboratory in Toronto; and Beta - 78573 CAMS 17566 and Beta - 78574 collagen extracted at Beta Analytic Inc. in Miami), that might account, at least in part, for the apparent age disparity (R. Beukens, pers. comm., 1995). Or the age disparity could be related to different levels of contamination in the bones. We consider it unlikely that the remains of two bison of different ages were tranported by a stream into the lake, since the bones were found together, are of similar appearance, and none is replicated.

Evidently giant bison (Bison cf. B. latifrons) and Columbian mammoths (Mammuthus cf. M. columbi) both lived in central British Columbia near the end of the Olympia Nonglacial Interval, since a rib fragment, excavated with other parts of a mammoth skeleton from silty pond deposits overlain by a thick layer of glacial till at Babine Lake, yielded a radiocarbon age of $34000 \pm 690 \mathrm{BP}$ (GSC - 1754) (Harington et al., 1974). The Babine Lake fossil locality is about $170 \mathrm{~km}$ WSW of the bison site (Fig. 1).

\section{PALEONTOLOGY}

\section{PRESERVATION OF BISON BONES}

When the ten bison bones were discovered in 1967, most were lying together within the laminated silt and clay (Unit 1 of station 91-264), and only a few pieces were located downstream from station 91-264 as they were reworked by the Nation River (P. Koropatnisky, pers. comm., 1993). This distribution suggests that the bones were not transported into the lake of Unit 1 from an external source; otherwise only a few fragments would have been found at one site, as most of them would have been dispersed during transport. Perhaps the bison fell through thin ice and the animal drowned in the lake. In this connection, it is worth noting that a large concentration of well-preserved steppe bison (Bison priscus) bones, radiocarbon dated to about $12000 \mathrm{BP}$ from Old Crow
River Locality 11(1), Yukon Territory, may have resulted from a herd of bison breaking through lake ice and dying (Harington, 1977). Fuller (1962, p. 38) reported that many bison in Wood Buffalo National Park are known to have drowned by breaking through thin or rotting ice in early winter or late spring. Or, perhaps a more likely scenario (accounting for the fragmentary, gnawed bones) would involve a bison killed by predators on winter lake ice, followed by dismemberment of the carcass, and sinking of the remains to the lake bottom the following spring. Additional fracture, displacement and signs of erosion could have resulted from erosion and deformation of the bones by overriding glacial ice (represented by the massive diamicton of Unit 2; Fig. 2) - presumably the bones were in place near the top of Unit 1. It is worth noting that Burns (1986) has postulated breaking through river ice as a scenario for preservation of an early Holocene wapiti (Cervus elaphus) skeleton near Watino, Alberta.

\section{PALYNOLOGY}

In order to reconstruct the bison's paleoenvironment, sediment from Unit 1, collected at the same level as the bones, was analyzed for pollen content, and the results were compared with modern pollen assemblages from British Columbia, Alberta and Yukon. The surface of the section was cleaned and the sample was bagged at the sampling site to avoid contamination. Pollen separtations followed the method developed by Erdtman (1960), i.e. they were digested with $\mathrm{KOH} 10 \%, \mathrm{HF} 49 \%, \mathrm{HCl} 50 \%$ and acetolyzed. Pollen grains of Eucalyptus globulus, an exotic species, were added to the samples to determine pollen concentration, according to Benninghoff's (1962) method. Residues were rinsed with butanol and stored in silicon oil. One hundred grains were counted to determine percentages of the most abundant pollen types.

The pollen assemblage of Unit 1 is dominated by arboreal pollen types $(67 \%)$ with Picea (39\%) and Betula (27\%) being the most abundant (Table II) (most Betula pollen grains are $>20 \mu \mathrm{m}$ suggesting that they are of arboreal type). Shrub and herb pollen, mostly Alnus (8\%), Shepherdia canadensis ( $8 \%$ ), 
TABLE II

Comparative pollen and spore percentages based on tree, shrub and herb total pollen counts from Middle Wisconsinan vertebrate fossil sites at Chuchi Lake and Babine Lake, and a modern site, Tezzeron Lake, British Columbia

\begin{tabular}{ccc}
\hline Unit 1 & $\begin{array}{c}\text { Babine } \\
\text { Lake } \\
\text { (this paper) } \\
\text { (Harington } \\
\text { et al., 1974) }\end{array}$ & $\begin{array}{c}\text { Tezzeron } \\
\text { Lake } \\
\text { (this paper) }\end{array}$ \\
\hline
\end{tabular}

\section{Trees}

Picea (spruce)

Pinus (pine)

Abies (fir)

Betula (birch)

Populus (poplar

or aspen)

Larix

Tsuga canadensis

Quercus

Shrubs

Alnus (undifferentiated)

Salix (willow)

Juniperus (juniper)

Shepherdia canadensis

Herbs

Gramineae (grass family)

Tubuliflorae

Liguliflorae

(undifferentiated)

Artemisia

Rumex (sorrel)

Saxifragaceae (saxifrage family)

Rosaceae (rose family)

Rosa (rose)

Spiraea

Geum (avens)

Caryophyllaceae (pinks family)

Thalictrum (meadow rue)

Epilobium (willow-herb)

Polygonum

Pteridophyta (ferns)

Selaginella densa

(prairie selaginella)

Unidentified

$\begin{array}{rrr}39.3 & 3.5 & 8.3 \\ 1.1 & 0.7 & 82.7 \\ & 0.4 & 2.3 \\ 27.0 & 32.2 & 1.0 \\ & & \\ & 2.8 & 0.2 \\ & & 0.7 \\ & & 0.2\end{array}$

7.9

0.2

6.4

0.4

7.9

6.7

1.1

16.0

0.7

12.0

0.4

0.4

2.7

1.4

0.2

0.2

1.9

0.5

2.1

0.4

0.8

0.2

3.4

Wetland

Cyperaceae (sedge family)

12.4

3.0

0.5

Aquatics

Sparganium (bur-reed)

Myriophyllum (water milfoil)

Spores
Gramineae (7\%) and Artemisia (4\%), are present in smaller amount. Cyperaceae pollen is well represented (12\%). Pollen concentration in the sample is $15871 \mathrm{grains} / \mathrm{cm}^{3}$.

In order to compare the Unit 1 assemblage with a modern pollen assemblage in this area, a sample collected from Tezzeron Lake (approximately $50 \mathrm{~km}$ south of Chuchi Lake) has been analyzed and is reported here (Table II). The modern pollen spectrum for Tezzeron Lake is dominated by arboreal pollen types (95\%) with the predominance of Pinus and Picea. Shrubs are poorly represented (approximately $5 \%$ ) and herb pollen is absent. Pollen concentration in this modern lake sediment sample is 233232 grains $/ \mathrm{cm}^{3}$.

Compared with other modern lake-sediment pollen assemblages from British Columbia, Alberta and Yukon (MacDonald and Ritchie, 1986), that of Tezzeron Lake is typical of subalpine forest spectra which corresponds to the forest region of this area as defined by Rowe (1972). In contrast, the pollen assemblage from Unit 1 is most similar to modern northern boreal forest assemblages (MacDonald and Ritchie, 1986). However, in Unit 1, pollen percentages from the shrub Shepherdia canadensis, and the herbs Gramineae and Artemisia are anomalously high compared to modern analogues from the northern boreal forest region (MacDonald and Ritchie, 1986). Because Artemisia is not a high pollen producer, its moderate pollen percentage indicates its presence in the local flora. The presence of Graminaeae and Artemisia indicates that the forest was relatively open. Therefore, we suggest that the pollen assemblage of Unit 1 reflects an open forest with an arboreal component similar to the modern northern boreal forest. Because the Chuchi Lake area is presently occupied by a subalpine forest, the pollen assemblage of Unit 1 reveals cooler climatic conditions some 36000 to 30000 years ago in central British Columbia.

The much lower pollen concentration in Unit 1 compare to modern lake sediment could indicate that (1) the sedimentation rate of Unit 1 was much more rapid than in modern lakes and/or (2) the density of pollen produced by the early forest was much less than that of a modern forest. A high sedimentation rate for Unit 1 is probable because it might have been deposited at the beginning of the Fraser Glaciation when sediment supply to the lake increased due to glacial erosion.

At the Babine Lake mammoth locality, the pollen assemblage recovered from organic silt associated with the bones is dominated by Betula, with minor amounts of Picea, Artemisia and Salix also well represented (Table II) (Harington et al., 1974). Compared with modern pollen assemblages, this pollen spectrum was interpreted to be a shrub tundra environment reflecting climatic conditions cooler than present (Harington et al., 1974) because the area is presently occupied by subalpine forest (Rowe, 1972). The age of this pollen assemblage is questionable because pieces of wood associated with the mammoth remains yielded radiocarbon ages of $42900 \pm 1860$ BP (GSC-1657) and $43800 \pm 1830$ BP (GSC$1687)$ whereas analysis of the mammoth bone yielded a date of $34000 \pm 690 \mathrm{BP}$ (GSC-1754) (Harington et al., 1974). From the Babine Lake and Chuchi Lake sites, it seems that the paleoclimatic conditions were cooler than present, at least for 
some time, approximately 40000 to 30000 years ago. However, more precise conclusions on the paleoclimatic conditions of central British Columbia during the Olympia Nonglacial Interval, based on these sites, should not be made.

\section{THE CHUCHI LAKE BISON}

\section{Systematic description}

Bison cf. B. latifrons (Harlan), 1825

\section{Giant Bison}

Referred specimens: Skull - Left horncore tip region (47M38A) (Fig. 4). [The specimen used for comparative purposes in determining the characteristics of both horncore fragments from Chuchi Lake is NMC 33990, Bison alaskensis from Dawson Locality 10 (Hunker Creek), Yukon Territory, which consists of a posterior cranial fragment with the base of the left horncore and complete right horncore attached.] The tip region is from a left horncore because the steepest side of the deep dorsal groove is anterior. Further, a broad, shallow groove on the posteroventral surface is also seen in NMC 33990. Scaling 47M38A against NMC 33990, C.R.H. estimates that approximately $60 \mathrm{~mm}$ is missing from the tip, which, when added to the original measurement would yield a restored length along the upper surface of about $230 \mathrm{~mm}$ $(170+$ approximately $60 \mathrm{~mm})$. Right horncore fragment (47M38B) consisting of the main body of the horncore lacking a large part of the base (to the burr) and the tip (similar in length to that of the left tip region). Compared to $B$. alaskensis (NMC 33990) this specimen has relatively little upward curvature. Since the calculated average degree of taper on either side of the "missing" region between $47 \mathrm{M} 38 \mathrm{~A}$ and $47 \mathrm{M} 38 \mathrm{~B}$ is $23 \mathrm{~mm}$ per $4 \mathrm{~mm}$ of anteroposterior diameter, and $4 \mathrm{~mm}$ diameter separates the distal end of this fragment from the proximal end of the tip, the missing portion is estimated to be $23 \mathrm{~mm}$ long on the upper surface. It is more difficult to calculate the missing basal portion of the horncore from the proximal end of this specimen to the hypothetical position of the burr along the upper surface. This part of the horncore shows deeper grooving on the anterior surface (as in NMC 33990), indicating that it is from the right side. Using the zone of deepest grooving as a rough datum, and NMC 33990 as a guide, it is estimated that at least $150 \mathrm{~mm}$ is missing along the upper surface to the burr. Incorporating the preceding calculations for $47 \mathrm{M} 38 \mathrm{~A}$, the estimated total length along the upper curve of the horncore (burr to tip) for this bison specimen is $753^{+} \mathrm{mm}$ [ 230 (length of $\left.47 \mathrm{M} 38 \mathrm{~A}\right)+23$ (estimated "missing" length between the proximal end of $47 \mathrm{M} 38 \mathrm{~A}$ and the distal end of $47 \mathrm{M} 38 \mathrm{~B}$ portions) +350 (length of $47 \mathrm{M} 38 \mathrm{~B}$ ) $+150^{+}$(missing basal portion to burr of $47 \mathrm{M} 38 \mathrm{~B}$ )]. All measurements on the following postcranial bones are in millimetres $(\mathrm{mm})$.

Vertebra - Fifth cervical (47M11) lacking most of the neural spine, right articular process, and transverse processes. The superior and anterior surfaces of the centrum show signs of erosion. Since the epiphyseal plates of the centrum are fused to the body, an adult is represented. Measurements: centrum (anterior height) 48.6, centrum (maximum anterior width) 42.4, centrum (superior length) 69.7, neural canal (height) 32.6,

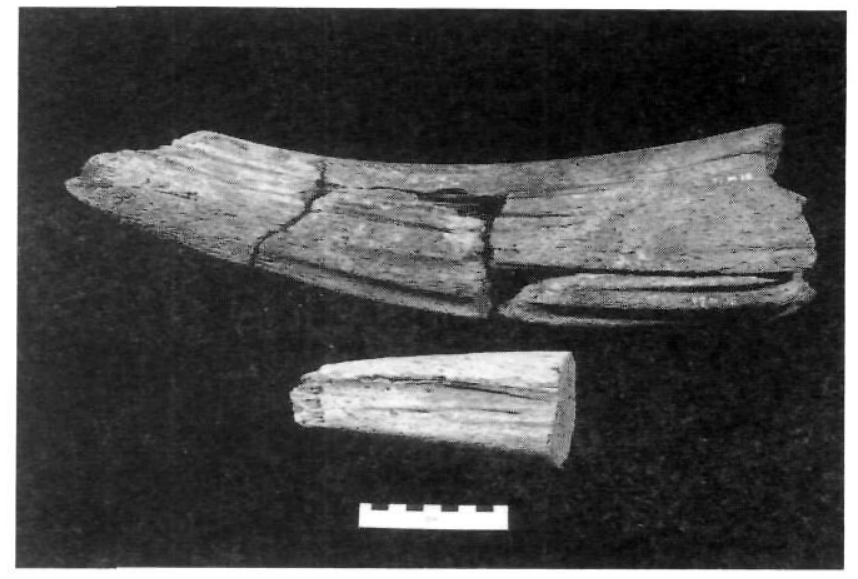

FIGURE 4. Top view of Bison cf. B. latifrons left horncore tip region (47M38A) below an anterior view of a large, central part of the right horncore of the same individual (47M38B). Note that part of the tip has been cut to provide a bone sample for AMS radiocarbon dating. The sample yielded a collagen date of $30740 \pm 220 \mathrm{BP}$ (TO3653) (GSC photograph no. 1992-327A).

Ossement du bas : vue supérieure de la pointe du noyau de la corne gauche (47M38A) d'un bison géant (Bison cf. B. latifrons). Noter qu'une partie de la pointe a été coupée pour fin de datation au radiocarbone. L'échantillon a donné un âge de $30740 \pm 220$ BP (TO3653). Ossement du haut: vue antérieure d'une grande partie du noyau de la corne droite du même individu.

neural canal (width) 35.0, minimum width between transverse foramina 87.3.

Forelimbs - Right humerus (47M3) lacking the proximal portion above the base of the deltoid tuberosity. The large size of the bone, epiphyseal fusion, and its well developed surface sculpture indicates an adult. Fractures on the shaft show signs of erosion not inconsistent with erosion of the bone that may have occurred during overriding of glacial ice (see Preservation of Bison Bones section). The distal articular surfaces also show signs of erosion. Iron-staining has penetrated the shaft from the surface of the periosteum, suggesting a relatively long period of burial with active ground water. Measurements: minimum width shaft $62.5 \mathrm{~mm}$, minimum depth shaft $73.7 \mathrm{~mm}$, maximum distal depth 128.0, maximum distal width 115.8, minimum depth of articular (condylar) surface 54.8. Right radio-ulna (47M4 and 47M27) lacking the proximal half of the ulna. The specimen has several longitudinal cracks on the shaft, but there is little sign of surface erosion. Measurements: radius: (length) $400 \mathrm{~mm}$, (proximal width) 124.0, (proximal depth) 63.2, (midshaft width) $66.0 \mathrm{~mm}$, (midshaft depth) $42.6 \mathrm{~mm}$, maximum distal width $115.4 \mathrm{~mm}$, (distal depth) $70.7 \mathrm{~mm}$.

Hindlimbs - Left tibia (47M2) lacking the proximal half. It displays longitudinal cracks and apparently the fracture on the shaft was not made on fresh bone because it is a jagged rather than a spiral fracture. Possible gnaw marks are seen on the anteromedial portion of the shaft near the break. Ironstaining has penetrated the shaft. Measurements: midshaft width 62.4 , midshaft depth 48.4 , maximum distal width 93.8 , distal depth 71.2. Left cuneiform (tarsal bone) (47M17). The bone is complete and slightly iron-stained. Measurements: maximum anteroposterior depth 36.4 , maximum mediolateral 
width 56.2. First phalanx (47M24a-1) - possibly from the left hindlimb (medial). Measurements: maximum length 88.5 , proximal width 45.2 , proximal depth 52.4 , midshaft width 40.7 , minimum shaft depth 29.5, distal width 43.6, distal depth 39.0. First phalanx (47M24a-2) - possibly from the left hindlimb (lateral). Measurements: maximum length 89.4 , proximal width 44.8 , proximal depth 50.0 , midshaft width 39.1 , minimum midshaft depth 26.6 , distal width 40.5 , distal depth 32.6. Third phalanx (47M24c). Measurements: maximum height 48.5, maximum anteroposterior depth 97.0, width of articular surface 33.1.

\section{DISCUSSION}

The estimated total length along the upper surface (burr to tip) of a "reconstructed" horncore from the Chuchi Lake bison of more than $753 \mathrm{~mm}$ lies below the mean, but within the upper part of the lower range for Bison latifrons and well above the mean and range for Bison alaskensis (Skinner and Kaisen 1947, Tables 18, 19; Table III), which some authors synonymize with B. priscus (Kurtén and Anderson, 1980). Compared to statistical data calculated by McDonald (1981, Tables 17, 40; Table III), the Chuchi Lake specimen lies below the mean, but within the middle range of $B$. latifrons males, and well above the range of $B$. latifrons females. Further, the Chuchi lake specimen lies well above the mean and within the upper range for $B$. alaskensis males, and well above the mean and range of $B$. alaskensis females. Therefore, using this horncore measurement as the prime criterion, the Chuchi Lake specimen as conservatively "reconstructed" is best referred to the giant bison (Bison cf. B. latifrons).

The Chuchi Lake find is of interest because the horncore remains are sufficiently complete to make an estimate of its horncore length along the upper curve from tip to burr. The estimate indicates that an adult bison with extremely large horns is represented, and that it is best referred to the giant bison using comparative statistical measurements provided by Skinner and Kaisen (1947) and McDonald (1981). The Chuchi Lake horncore, as estimated here, and the humerus, radius and tibia measurements are fairly close to those of a partial skeleton of $B$. latifrons (University of Florida Vertebrate Paleontology collection 7559) from the Haile VIIIA site, Florida, of probable last (Sangamonian) interglacial age (Robertson, 1974; Table IV).

The Chuchi Lake specimen is the first evidence of giant bison in British Columbia (Harington, 1979; in press). It may have shared lake-dotted, open forest to shrub tundra range with Columbian mammoths in central British Columbia about 36000 to 30000 years ago, during the Olympia Nonglacial Interval (Harington et al., 1974). McDonald (1981, p. 73) notes that the distribution pattern of the species suggests that it was ..."probably a browser-grazer primarily adapted to forest openings or woodlands...".

Bison latifrons, characterized by large body size and extremely long horns, was confined to North America, and lived from at least the second last (Illinoian) glaciation to Late Wisconsinan time [a terminal date between 30000 and $21000 \mathrm{BP}$ is indicated by material from Rainbow Beach, Idaho
TABLE III

Horncore upper curve length (tip to burr) measurements ( $\mathrm{mm}$ ) of a bison horncore from Chuchi Lake compared with those of Bison latifrons and Bison alaskensis

\begin{tabular}{|c|c|c|c|}
\hline \multirow{2}{*}{ Specimens } & \multicolumn{3}{|c|}{$\begin{array}{l}\text { Length along upper curve of horncore } \\
\text { (tip to burr) }\end{array}$} \\
\hline & Mean & $\begin{array}{l}\text { Observed } \\
\text { range }\end{array}$ & $\begin{array}{l}\text { Number } \\
\text { in sample }\end{array}$ \\
\hline $\begin{array}{l}\text { Bison cf. B. latifrons } \\
\text { Chuchi Lake, BC } \\
\text { (this paper) }\end{array}$ & $753^{+}$(estimated) & - & 1 \\
\hline $\begin{array}{l}\text { Bison latifrons } \\
\text { North America } \\
\text { (Skinner \& Kaisen } \\
\text { 1947, Table 19) }\end{array}$ & 830 & $650-1115$ & 12 \\
\hline $\begin{array}{l}\text { Bison alaskensis } \\
\text { North America } \\
\text { (Skinner \& Kaisen } \\
\text { 1947, Table 18) }\end{array}$ & 498 & $475-520$ & 2 \\
\hline $\begin{array}{l}\text { Bison latifrons } \\
\text { North America } \\
\text { (McDonald 1981, } \\
\text { Table 17) }\end{array}$ & & & \\
\hline Males & 876 & $551-1091$ & 25 \\
\hline Females & 564 & $519-653$ & 3 \\
\hline $\begin{array}{l}\text { Bison alaskensis } \\
\text { North America } \\
\text { (McDonald 1981, } \\
\text { Table 40) }\end{array}$ & & & \\
\hline Males & 553 & $426-795$ & 36 \\
\hline Females & 319 & $288-388$ & 6 \\
\hline
\end{tabular}

TABLE IV

Horncore upper curve length (tip to burr) and limb bone measurements $(\mathrm{mm})$ of the Chuchi Lake specimen compared with those of Bison latifrons from the Haile VIIIA site, Florida

\begin{tabular}{lcc}
\hline $\begin{array}{l}\text { Elements and } \\
\text { measurements }\end{array}$ & $\begin{array}{l}\text { Chuchi Lake specimen, } \\
\text { British Columbia } \\
\text { (Middle Wisconsinan) }\end{array}$ & $\begin{array}{l}\text { Haile VIIIA specimen, } \\
\text { Florida (Sangamonian) } \\
\text { (McDonald, 1981, } \\
\text { Table 45) }\end{array}$ \\
\hline $\begin{array}{l}\text { Horncore length } \\
\text { on upper curve }\end{array}$ & $753+$ & 795 \\
$\begin{array}{l}\text { Humerus } \\
\quad \text { Shaft depth }\end{array}$ & 73.7 & 73.0 \\
$\quad$ Shaft width & 62.5 & 60.0 \\
Radius & & \\
$\quad \begin{array}{l}\text { Shaft depth } \\
\text { Shaft width }\end{array}$ & 42.6 & 41.0 \\
Tibia & 66.0 & 65.0 \\
$\quad$ Shaft depth & & \\
Shaft width & 48.4 & 63.0 \\
\hline
\end{tabular}


(Kurtén and Anderson, 1980)]. McDonald's (1981, Fig. 18) map of $B$. latifrons localities shows that they roamed from California to Florida and Mexico to North Dakota, with concentrations in California, Idaho (where an associated skull and skeleton was found at American Falls), near the $100^{\circ} \mathrm{W}$ meridian from the Dakotas to Texas, and in Florida. The species was widespread in Sangamonian interglacial time (Kurtén and Anderson 1980). Despite McDonald's map, bison, including giant bison, may have had a broad Sangamonian distribution in Canada (Toronto, Ontario; Fort Qu'Appelle and Saskatoon, Saskatchewan; Medicine Hat and Watino, Alberta; Westwold, British Columbia; Old Crow Basin, Yukon Territory) (Harington, 1990). Also, it is worth noting that Fuller and Bayrock (1965) referred a massive horncore with unusually strong upward curvature (UA 627) from the Edmonton area to Bison latifrons. Another Edmonton specimen with similar characteristics (NMC 26055) - like the holotype of Bison alleni (see Skinner and Kaisen, 1947) - has been referred to Bison alaskensis (McDonald, 1981, Table 41). The best evidence of Bison latifrons in Canada is from Fort Qu'Appelle (Khan, 1970), and Stalker and Churcher (1982) report Bison cf. B. latifrons from Sangamonian deposits at Medicine Hat. Apparently the Chuchi Lake specimen is one of the latest known giant bison survivors.

\section{ACKNOWLEDGMENTS}

We are grateful to: P. Koropatnisky of Chuchi Lake for collecting the specimens and for consultation in the field; Charles E. Borden (deceased) and D. Pokotylo (University of British Columbia Museum of Anthropology, Vancouver, where the specimens are kept) for storing and preserving them, and for allowing us to borrow, describe and use material for radiocarbon age determinations; and the Canadian Museum of Nature for supporting the laboratory study of the specimens. The field study was part of a regional surficial sediment mapping project undertaken by the Geological Survey of Canada and financed by the Canada-British Columbia Agreement on Mineral Development. The stratigraphy and paleoecology presented in this paper are part of a Ph.D. thesis undertaken by the second author at the University of Montréal under the supervision of M.A. Bouchard and W.W. Shilts. We are grateful to R.J. Mott for his constructive comments on the palynology section, and to Dr. R. Beukens (IsoTrace Laboratory) for advice on problems of radiocarbon dating bones and collagen extraction. Kieran Shepherd kindly assisted C.R.H. in repairing the larger of the two horncore fragments (47M38B). W. Blake Jr. improved the first version of the manuscript, and $\mathrm{E}$. Anderson and A. Beaudoin constructively reviewed the paper. Gail Rice kindly word-processed the manuscript.

\section{REFERENCES}

Benninghoff, W.S., 1962. Calculation of pollen and spore density in sediments by addition of exotic pollen in known quantities. Pollen et spores, 4: 232233.
Burns, J.A., 1986. A 9000 - year old wapiti (Cervus elaphus) skeleton from northern Alberta, and its implications for the Early Holocene environment. Géographie physique et Quaternaire, 40: 105-108.

Church, M. and Ryder, J.M., 1972. Paraglacial sedimentation: A consideration of fluvial processes conditioned by glaciation. Geological Society of America Bulletin, 83: 3059-3072.

Erdtman, G., 1960. The acetolysis method, a revised description. Svensk Botanisk Tidskrift, 54: 561-564.

Eyles, N. and Miall, A.D., 1984. Glacial facies. p. 15-38. In R.G. Walker, ed. Facies models. Geoscience Canada reprint series 1, Geological Association of Canada, Toronto.

Fuller, W.A., 1962. The biology and management of the bison of Wood Buffalo National Park. Canadian Wildlife Service, Wildlife Management Bulletin, Series 1, 16: 1-52.

Fuller, W.A. and Bayrock, L.A., 1965. Late Pleistocene mammals from central Alberta, Canada, p. 53-63. In R.E. Folinsbee and D.M. Ross, eds., Vertebrate paleontology in Alberta. University of Alberta Press, Edmonton.

Harington, C.R., 1977. Pleistocene mammals of the Yukon Territory. Ph.D. thesis, University of Alberta, Edmonton, $1060 \mathrm{p}$.

1979. Wildlife and man in B.C. during the ice age, p. 142-147. In A Downs, ed., Pioneer Days in British Columbia, Volume 4. Heritage House, Surrey.

1990. Vertebrates of the last interglaciation in Canada: A review, with new data. Géographie physique et Quaternaire, 44: 375-387.

- in press. Quaternary animals: Vertebrates of the ice age. In R. Ludvigsen, ed., British Columbia fossils: Worlds to discover. University of British Columbia Press, Vancouver.

Harington, C.R., Tipper, H.W. and Mott, R.J., 1974. Mammoth from Babine Lake, British Columbia. Canadian Journal of Earth Sciences, 11: 285-303.

Jackson, L.E., MacDonald, G.M. and Wilson, M.C., 1982. Paraglacial origin for terraced river sediments in Bow Valley, Alberta. Canadian Journal of Earth Sciences, 19: 2219-2231.

Khan, E., 1970. Biostratigraphy and palaeontology of a Sangamon deposit at Fort Qu'Appelle, Saskatchewan. National Museums of Canada, Publications in Palaeontology, 5: 1-82.

Kurtén, B. and Anderson, E., 1980. Pleistocene mammals of North America. Columbia University Press, New York. 442 p.

MacDonald, G.M. and Ritchie, J.C., 1986. Modern pollen spectra from the western interior of Canada and the interpretation of late Quaternary vegetation development. New Phytologist, 103: 245-268.

McDonald, J.N., 1981. North American bison: Their classification and evolution. University of California Press, Berkeley, $316 \mathrm{p}$.

Plouffe, A., 1992. Quaternary stratigraphy and history of central British Columbia. In Current Research, Part A, Geological Survey of Canada, Paper 92-1A: 189-193

Robertson, J.S., Jr., 1974. Fossil bison of Florida, p. 214-246. In S.D. Webb, ed., Pleistocene mammals of Florida. University Presses of Florida, Gainesville.

Rowe, J.S., 1972. Forest regions of Canada. Canadian Forestry Service, Department of the Environment, Ottawa, Publication 1300, $172 \mathrm{p}$.

Ryder, J.M. and Clague, J.J., 1989. British Columbia (Quaternary stratigraphy and history, Cordilleran (ce Sheet), p. 48-58. In R.J. Fulton, ed., Quaternary geology of Canada and Greenland. Geological Survey of Canada, Geology of Canada, no. 1.

Skinner, M.F. and Kaisen, O.C., 1947. The fossil Bison of Alaska and preliminary revision of the genus. Bulletin of the American Museum of Natural History, 89: 123-256.

Stalker, A.M. and Churcher, C.S., 1982. Ice age deposits and animals from the southwestern part of the Great Plains of Canada. Geological Survey of Canada, Miscellaneous Report 31 (wall chart). 